\title{
Stages of grassland degradation in subalpine ecosystems of the Central Caucasus, Russia
}

\author{
Victoria Chadaeva $^{1 *}$, Olga Gorobtsova ${ }^{1}$, Rustam Pshegusov $^{1}$, Nelli Tsepkova ${ }^{1}$, \\ Rustam Tembotov ${ }^{1}$, Zalim Khanov ${ }^{1}$, Fatima Gedgafova ${ }^{1}$, Albert Zhashuev ${ }^{1}$, \\ Tatyana Uligova ${ }^{1}$, Elena Khakunova ${ }^{1}$, and Elena Stepanyan ${ }^{1}$
}

${ }^{1}$ Tembotov Institute of Ecology of Mountain Territories of Russian Academy of Science, 360051 Nalchik, Russia. "Corresponding author (v_chadayeva@mail.ru).

Received: 28 April 2021; Accepted: 31 August 2021; doi:10.4067/S0718-58392021000400630

\begin{abstract}
Overgrazing and grassland degradation are significant environmental problems in the mountain ecosystems of the Central Caucasus. The aim was to define the criteria for the stages of grassland degradation to provide land managers with useful guidelines on evaluating grassland status. We identified four stages of grassland degradation based on a statistical analysis of 23 vegetation and soil parameters at 126 model plots in the subalpine meadows. Main indicators of grassland degradation were grass height, coverage of forage species, coverage of grazing-resistant species, and fresh herbage yield. Grass height decreased significantly $(\mathrm{P}<0.05)$ with each stage of grassland degradation from $31.4 \pm 3.6 \mathrm{~cm}$ in untransformed grasslands to $3.3 \pm 1.7 \mathrm{~cm}$ in severely degraded pastures. Fresh herbage yield in untransformed grasslands $\left(120.8 \pm 12.5 \times 10^{2} \mathrm{~kg} \mathrm{ha}^{-1}\right)$ was $81 \%$ higher than in highly degraded pastures. Coverage of forage species decreased in the row of grassland degradation from $72 \%$ to $34 \%$, while coverage of grazing-resistant species increased with grazing intensity from $23 \%$ to $77 \%$. Critical values of the integral degradation index based on these four parameters are useful for a reliable assessment of grassland status in the field.
\end{abstract}

Key words: Grassland assessment, grazing intensity, indicators of grassland degradation.

\section{INTRODUCTION}

Grasslands are important land biomes that provide many indispensable ecosystem services globally, including fodder supply and erosion control, $\mathrm{C}$ sequestration and biodiversity conservation, water regulation and sand fixation, cultural and recreational services (Amidzic et al., 2020). The level of ecosystem services of grasslands depends on the state of vegetation and soil, but anthropogenic land use (agriculture, urbanization, etc.) causes their severe degradation. Longterm overgrazing is a key factor in grassland degradation that changes the composition of dominant species and the distribution of forage and poisonous species in grasslands (Leu et al., 2014; Zhang et al., 2014; Lazareva et al., 2020). Grazing intensity induces divergent responses in soil organic matter, bulk density, moisture, and microbial parameters (Leu et al., 2014; Liu et al., 2021). However, a long-term grazing exclusion also has significant negative effects on the state of grasslands, coursing an increase in plant litter and coverage of poisonous species, shrubs (Navarro and Pereira, 2012). Therefore, determining suitable grazing intensity is of great importance in sustainable grassland management and profitable land use (Zhang et al., 2014). Suitable stocking rates are difficult to predict due to poor understanding of vegetation and soil indicators of the grassland degradation stages (DSs). Grassland status can be assessed by various parameters of vegetation, soil and landscape, depending on grassland type, climate, relief, etc. (Zhang et al., 2014; Lazareva et al., 2020; Lee et al., 2020). Thus, there is uncertainty in the assessment tools for grassland status identification, while the reliable indicators of DSs can optimize pasture management. 
Scarcity of information on DSs indicators and suitable stocking rates is an urgent problem for grassland management in the Central Caucasus. Caucasian grasslands are one of the most important grazing ecosystems in southern Russia for both sustainable livestock production and conservation of biodiversity. Grazing has been the most important land use in the Caucasus for millennia, so all mountain grasslands in the region are presently semi-natural grazing ecosystems. These ecosystems have problems similar to those throughout the grassland ecosystems of China, Kenya, and other countries: overgrazing due to pasture compression, and restriction of herd mobility caused by misguided economic policies (Boles et al., 2019; Dong et al., 2021; Su et al., 2021). Market-oriented grassland rental has been prevalent since 2010. It grants use rights to individual herders within small land plots and results in a loss of mobility in grassland use, combined with overgrazing of rental rangelands. Therefore, grassland management practices draw a lot of attention these days. Nevertheless, there is very limited information regarding the effects of grazing intensity on soil and vegetation quality. Due to scarcity of this information, the contribution of Caucasian grasslands to the global scientific discourse is sparse.

Therefore, the aim of this study was to define the criteria for the stages of grassland degradation to provide land managers with useful guidelines on evaluating the grassland status in the field. This study presents the integral grassland degradation index (DI) based on the main vegetation and soil indicators. The findings strengthen the theoretical foundation of knowledge on pasture degradation regularities and may be useful for studying the effects of grazing intensity on grassland systems in other areas.

\section{MATERIALS AND METHODS}

\section{Study area}

Study was carried out in the subalpine ecoregion $\left(43^{\circ} 00^{\prime}\right.$ to $43^{\circ} 42^{\prime} \mathrm{N}, 42^{\circ} 27^{\prime}$ to $43^{\circ} 03^{\prime} \mathrm{E}, 1800$ to $2300 \mathrm{~m}$ a.s.1.), located in the central part of the North Caucasus, southern Russia (Figure 1). A relatively cold and humid continental climate

Figure 1. Location of Caucasus (A), Central Caucasus (B), and location of the studied area (C).

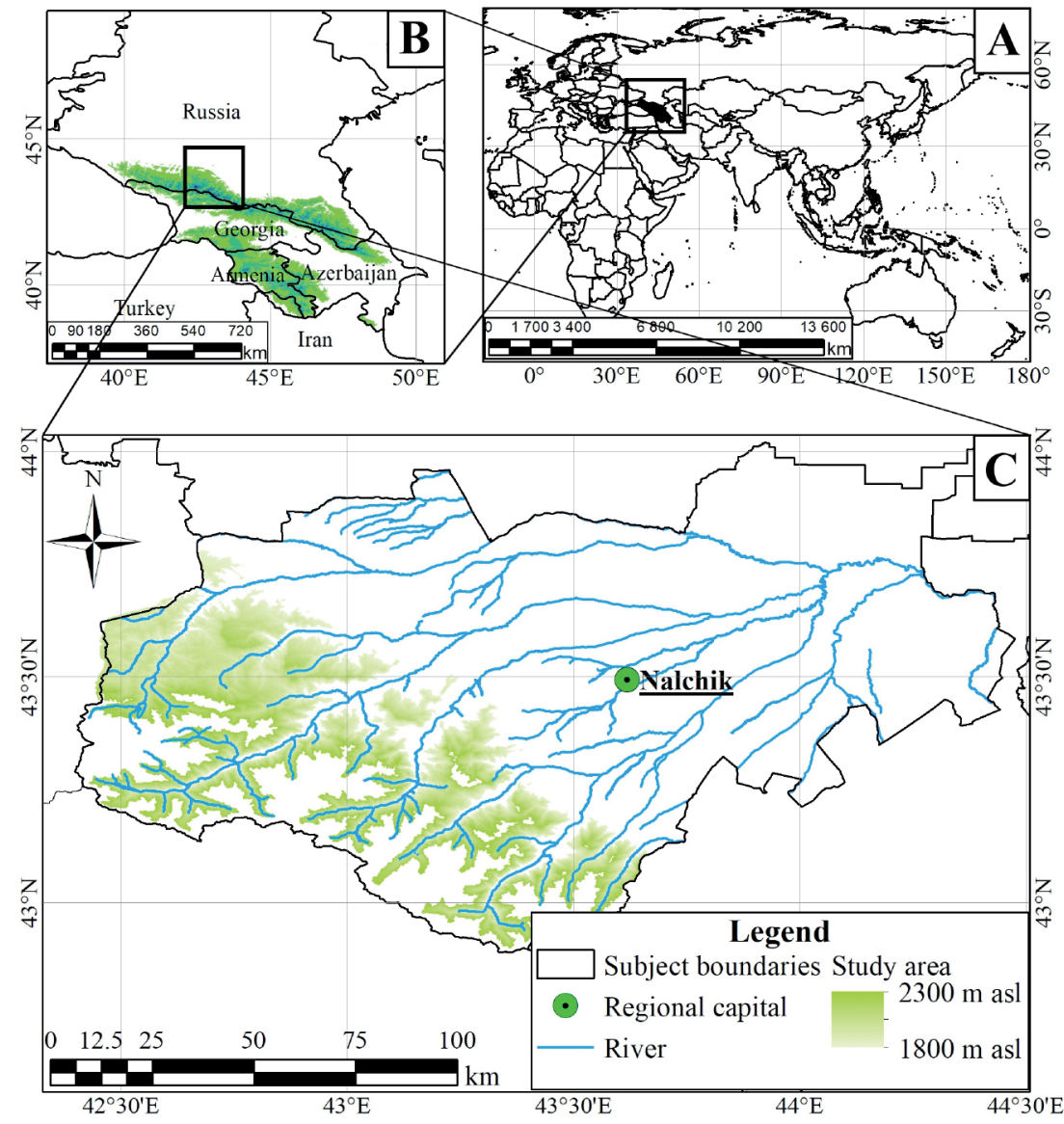


with a short plant-growing period from May to October characterizes the subalpine grasslands of the studied area. Mean daily temperature is $12.6{ }^{\circ} \mathrm{C}$ in January and $-6.7^{\circ} \mathrm{C}$ in December; the annual precipitation is approximately $900 \mathrm{~mm}$. The most common is a mountain meadow subalpine soil, which is primarily Rendzic Leptosols (according to the FAO classification). The main type of grasslands was a subalpine mesophytic meadow dominated by Bromus variegatus $\mathrm{M}$. Bieb., accompanied by Betonica macrantha K. Koch, Veronica gentianoides Vahl, Geranium sylvaticum L., Galium verum L., Carex humilis Leyss, etc. Bromus variegatus is a perennial species of Poaceae family, one of the most valuable forage plants in mesophytic meadows of the Central Caucasus, resistant to moderate grazing. The grasslands dominated by this species mostly occupy gently sloping landforms that are easily accessible for grazing. Untransformed grasslands remained only in areas remote from sheepfolds, watering holes, or within the boundaries of Kabardino-Balkaria High Mountain State Reserve and enclosed territories.

\section{Data collection and measurements}

In July 2020, we established 128 model plots within degraded grasslands with different stocking rates (from 3.15 to 70.45 sheep $\mathrm{ha}^{-1} \mathrm{~d}^{-1}$ ) and within untransformed grasslands. The model plots were located at the foot of slopes, on river terraces, and in floodplains with the same microrelief, slope exposure, and steepness. The area of each plot was $900 \mathrm{~m}^{2}$, and the total area of the studied territory was approximately $11.5 \mathrm{ha}$. We accepted sheep as an equivalent of grazing animals with the coefficients established in Russia (Order of the Ministry of Agriculture of the Russian Federation Nr 62 dated 13 January 2020): One sheep, 10 bovines, 10 yaks, 15 horses.

We took five soil samples from the topsoil $(0-20 \mathrm{~cm})$ of each model plot by the envelope method using a soil drill (70 $\mathrm{mm}$ diameter), and then thoroughly mixed all samples into one composite sample. Soil moisture (\%), and bulk density $\left(\mathrm{g} \mathrm{cm}^{-3}\right)$ were determined gravimetrically (Kazeev et al., 2003). Fresh weight was measured in the field using analytical balance (HTR-220CE, ViBRA, Shinko Denshi Co., Tokyo, Japan) and then samples were dried in an oven at $115{ }^{\circ} \mathrm{C}$ for $4 \mathrm{~h}$ (until the weight stabilized), cooled in desiccators for $60 \mathrm{~min}$ and re-weighed. To determine humus content (\%) and humus stock $\left(10^{3} \mathrm{~kg} \mathrm{ha}^{-1}\right)$, we used Tyurin method in Nikitin modification (Kazeev et al., 2003) and bulk density, respectively. Soil $\mathrm{pH}$ (soil-water suspension 1:2.5) was measured by the potentiometric method using $\mathrm{pH}$ meter $(\mathrm{pH}$ 211, Hanna Instruments, Woonsocket, Rhode Island, USA). Analytical redefining was 3-6-fold. We visually assessed vegetation coverage (both live grass and forbs) and coverage of each species on model plots $\left(900 \mathrm{~m}^{2}\right)$ and expressed as a percentage. Grass height $(\mathrm{cm})$ was recorded by the average height of cereal leaves. Species richness represented the total number of species within each plot. Proportion of synanthropic species (Cirsium obvallatum, C. rhizocephalum, Carduus nutans, Veratrum lobelianum, Urtica dioica, Rumex confertus, etc.) was a percentage of the species richness. We applied Shannon, Berger-Parker and Simpson indices to calculate the alpha diversity and evenness of plant communities. Rare species were obtained from Red Data Book of the Republic of Kabardino-Balkaria (2018). Plant species nomenclature follows Germplasm Resources Information Network (https:/npgsweb.ars-grin.gov/gringlobal/taxon/taxonomysearch). Few plant species that were not included in GRIN were checked with The Plant List (http://www.theplantlist.org).

We also determined the fodder value of grasslands and their resistance to grazing. For this purpose, we divided plant species into four functional groups, and for each group, we defined the coverage and number of species. They were a group of forage species (F-group), a group of grazing-resistant forage species (GRF-group), a group of less palatable and inedible species (LPI-group), and a group of grazing-resistant species (GR-group). F-Group included forage grazingsensitive species. GRF-Group consisted of palatable and preferred plants with dense turf or rosette life forms, creeping or fast-growing shoots. LPI-Group was a group of non-preferred and poisonous plants with an unpleasant taste, thorns, rough leaves, and sprawling shoots. GR-Group included both GRF- and LPI-groups, indicating the total grassland resistance to grazing. The list of main species of F-, GRF- and LPI-groups is shown in Table 1.

After the grassland monitoring was ended, the aboveground vegetation in three $0.25 \mathrm{~m}^{2}$ quadrants was cut, put in paper bags and weighed to determine fresh weight using a balance (20 kg capacity, WeiHeng Smile, Guangzhou, China). We then took samples to the lab and dried them to constant weight in an oven at $60^{\circ} \mathrm{C}$ to determine dry weight. We expressed fresh and dry herbage yield as fresh and DM per hectare $\left(10^{2} \mathrm{~kg} \mathrm{ha}^{-1}\right)$. The permissible stocking rates were calculated using the formula $\mathrm{PR}=\mathrm{FM} /(\mathrm{GF} \times \mathrm{DP})$, where $\mathrm{PR}$ is the permissible stocking rates $\left(\right.$ sheep $\left.\mathrm{ha}^{-1} \mathrm{~d}^{-1}\right), \mathrm{FM}$ is the fresh matter per hectare $\left(10^{2} \mathrm{~kg} \mathrm{ha}^{-1}\right), \mathrm{GF}=2.5 \mathrm{~kg}$ is the need for grazing forage per sheep, DP $=130 \mathrm{~d}$ is the average duration of pasture season. 
Table 1. The main plant species within functional groups in the study area.

\begin{tabular}{|c|c|c|c|}
\hline Species & $\begin{array}{l}\text { Functional } \\
\text { group }\end{array}$ & Species & $\begin{array}{l}\text { Functional } \\
\text { group }\end{array}$ \\
\hline Bromus variegatus M. Bieb. & $\mathrm{F}$ & Potentilla pimpinelloides L. & LPI \\
\hline Dactylis glomerata $\mathrm{L}$. & $\mathrm{F}$ & Pilosella officinarum F.W. Schultz \& Sch. Bip. & LPI \\
\hline Hordeum brevisubulatum (Trin.) Link & $\mathrm{F}$ & Veronica gentianoides Vahl & LPI \\
\hline Koeleria macrantha (Ledeb.) Schult. & $\mathrm{F}$ & Deschampsia cespitosa (L.) P. Beauv. & LPI \\
\hline Phleum alpinum $\mathrm{L}$. & $\mathrm{F}$ & Nardus stricta L. & LPI \\
\hline Phleum phleoides (L.) H. Karst. & $\mathrm{F}$ & Urtica dioica $\mathrm{L}$. & LPI \\
\hline Phleum pratense $\mathrm{L}$. & $\mathrm{F}$ & Salvia verticillata $\mathrm{L}$. & LPI \\
\hline Medicago lupulina $\mathrm{L}$. & $\mathrm{F}$ & Marrubium catariifolium Desr. & LPI \\
\hline Trifolium canescens Willd. & $\mathrm{F}$ & Phlomoides tuberosa (L.) Moench & LPI \\
\hline Trifolium pratense $\mathrm{L}$. & $\mathrm{F}$ & Thymus collinus M. Bieb. & LPI \\
\hline Carum carvi $\mathrm{L}$. & $\mathrm{F}$ & Betonica macrantha K. Koch & LPI \\
\hline Agrostis capillaris L. & GRF & Stachys atherocalyx K. Koch & LPI \\
\hline Festuca ovina $\mathrm{L}$. & GRF & Nepeta grandiflora M. Bieb. & LPI \\
\hline Festuca pratensis Huds. & GRF & Matricaria discoidea DC. & LPI \\
\hline Festuca valesiaca Schleich. ex Gaudin & GRF & Achillea millefolium $\mathrm{L}$. & LPI \\
\hline Carex humilis Leyss. & GRF & Astragalus captiosus Boriss. & LPI \\
\hline Trifolium ambiguum M. Bieb. & GRF & Nonea rosea (M. Bieb.) Link & LPI \\
\hline Trifolium repens $\mathrm{L}$. & GRF & Rumex confertus Willd. & LPI \\
\hline Alchemilla caucasica Buser & LPI & Anemone ranunculoides $\mathrm{L}$. & LPI \\
\hline Alchemilla orthotricha Rothm. & LPI & Ranunculus grandiflorus L. & LPI \\
\hline Alchemilla retinervis Buser & LPI & Ranunculus oreophilus M. Bieb. & LPI \\
\hline Alchemilla sericata $\mathrm{Rchb}$. & LPI & Veratrum lobelianum Bernh. & LPI \\
\hline Plantago atrata Hoppe & LPI & Aconitum orientale Mill. & LPI \\
\hline Plantago media L. & LPI & Aconitum nasutum Fisch. ex Rchb. & LPI \\
\hline Plantago major L. & LPI & Euphorbia seguieriana Neck. & LPI \\
\hline Carduus nutans L. & LPI & Euphorbia iberica Boiss. & LPI \\
\hline Cirsium obvallatum (M. Bieb.) Fisch. & LPI & Antennaria dioica (L.) Gaertn. & LPI \\
\hline Cirsium rhizocephalum C.A. Mey. & LPI & Potentilla bifurca $\mathrm{L}$. & LPI \\
\hline
\end{tabular}

F: Forage species; GRF: grazing-resistant forage species; LPI: less palatable and inedible species.

We used linear discriminant analysis (LDA) for independent groups of model plots to identify vegetation and soil indicators of degradation stages (DSs) (Statistica 10.0, TIBCO, Palo Alto, California, USA). One-way ANOVA and least significant difference (LSD) tests were applied to establish differences between the stages of grassland degradation. We constructed a multiple regression equation to calculate degradation index (DI) by main vegetation and soil parameters for each stage of grassland degradation. Shannon, Berger-Parker and Simpson indices were calculated using Past 4.0 (Hammer et al., 2001).

\section{RESULTS}

\section{Preliminary identification of DSs}

In the field, we preliminary identified the degradation stage (DS) of grassland at each of 128 model plots based on visual criteria. These criteria were composition of dominant plants, coverage of primary dominant Bromus variegatus, distribution of less palatable and inedible species, presence of bare ground, distance from sheepfolds and watering holes, and actual stocking rates. As a result, a preliminary four-stage system of DSs was developed. DS0 - untransformed grasslands dominated by B. variegatus (30\%-60\% of vegetation coverage). DS1 - least degraded grasslands dominated by B. variegatus (15\%-25\% of vegetation coverage), accompanied by Carex humilis, Festuca valesiaca, Agrostis capillaris, Alchemilla L.spp. and Trifolium L. spp. These grasslands were located in the middle-upper parts of slopes (gentle terraces with a slope percentage of 9\%-27\%), where the actual stocking rates did not exceed 3-10 sheep ha $\mathrm{d}^{-1} \mathrm{~d}^{-1}$. DS2 - moderately degraded grasslands with coverage of B. variegatus about 5\%-10\% and the dominance of grazing-resistant Alchemilla, Trifolium, C. humilis, A. capillaris, F. valesiaca, F. pratensis, Deschampsia cespitosa. These grasslands had a two-layer vertical structure (Poaceae and Cyperaceae species in the upper layer, forbs species in the lower layer) and did not have bare ground areas. The actual stocking rates were no more than 10-15 sheep ha- $\mathrm{d}^{-1}$. DS3 - severely degraded grasslands with bare ground and low grasses $1-3 \mathrm{~cm}$ in height. The dominant species of these grasslands were less palatable and 
inedible plants of Alchemilla, Trifolium, Plantago L. spp., Ranunculus L. spp., while the coverage of B. variegatus did not exceed 1\%-4\%. Cirsium obvallatum, Carduus nutans, Veratrum lobelianum, Urtica dioica, Rumex confertus, Euphorbia seguieriana, Nardus stricta were also widespread. The grasslands were often located at the foot of slopes and on river terraces near sheepfolds and watering holes.

\section{Statistical verification and vegetation and soil indicators of DSs}

According to the LDA for four independent groups of model plots (DS0, DS1, DS2, DS3) by 23 vegetation and soil parameters, there were only two previously incorrectly classified plots. After removing these plots from the analysis, the results of LDA (Wilks' Lambda $=0.00097$, approx. $\mathrm{F}(51.316)=57.591, \mathrm{P}<0.0000$ ) revealed clustering that supports DS0, DS1, DS2, DS3 as four separate stages of grassland degradation (Figure 2). The first two canonical roots (Root 1 and Root 2) accounted for about $98 \%$ of the overall variability in the sets of variables. Root 1 was formed by most of the studied vegetation and soil parameters, with the exception of the indices of diversity and dominance. Berger-Parker, Simpson, and Shannon indices had the highest factor loadings on Root 2 ( $0.62,0.40,-0.22$, respectively). Associations of the model plots corresponding to DS0, DS1, and DS2 tended to consistently shift from a positive quarter to a negative one in the scatterplot of the first two canonical roots. DS3 differed by vertical displacement to the area of positive values of Root 2, corresponding to the location of DS0.

Only 16 vegetation and soil parameters of model plots affected the DSs identification. Significance levels for these parameters were presented in Table 2. Vegetation parameters were more influential on DSs differentiation compared to soil parameters. Humus content and soil $\mathrm{pH}$ were the only significant $(\mathrm{P}<0.05)$ indicators among soil traits.

The difference between four DSs was significant $(\mathrm{P}<0.05)$ in only six parameters. They were grass height, coverage of GR- and F-groups of species, fresh and dry herbage yield, and number of rare species (Figure 3). Grass height, one of the most easily measured parameters in the field, decreased linearly from $31.4 \pm 3.6 \mathrm{~cm}$ to $3.3 \pm 1.7 \mathrm{~cm}$ in the row from DS0 to DS3. Fresh herbage yield at DS0 was $120.8 \pm 12.5 \times 10^{2} \mathrm{~kg} \mathrm{ha}^{-1}$, which was $26 \%$ higher than at DS1, and $62 \%$ higher than at DS2, and $81 \%$ higher than at DS3. Dry herbage yield at DS0 was $49.5 \pm 11.3 \times 10^{2} \mathrm{~kg} \mathrm{ha}^{-1}$, which was $37 \%$ higher than at DS1, and 56\% and 77\% higher than at DS2 and DS3, respectively. The changes in coverage of F- and GR-groups of species with degradation intensity determined the trends of decreasing the fodder value and increasing grazing resistance of grasslands. Number of rare species decreased with increasing grassland degradation. However, this parameter was excessively variable at DS0-DS2, which made it difficult to use number of rare species in the analysis.

Figure 2. Scatterplot of first two canonical roots (Root 1 and Root 2) of four grassland degradation stages (DS0-DS3) formed with linear discriminant analysis, considering 126 model plots.

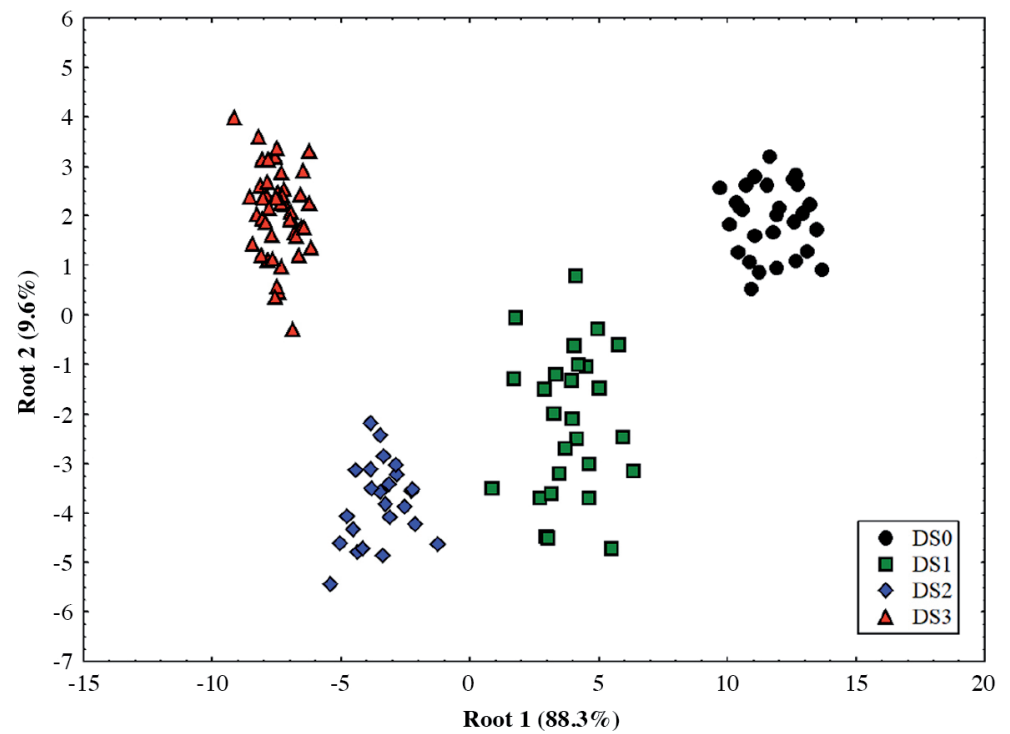

DS0: Untransformed grasslands; DS1: least degraded grasslands; DS2: moderately degraded grasslands; DS3: severely degraded grasslands. 
Table 2. Linear discriminant analysis data showing significance levels of vegetation and soil parameters in identification of the grassland degradation stages.

\begin{tabular}{|c|c|c|c|c|c|}
\hline Parameter & $\begin{array}{c}\text { Partial } \\
\text { Lambda }\end{array}$ & F-test & Parameter & $\begin{array}{c}\text { Partial } \\
\text { Lambda }\end{array}$ & F-test \\
\hline Grass height, $\mathrm{cm}$ & 0.749 & $* * *$ & Number of rare species & 0.894 & $* *$ \\
\hline Berger-Parker index & 0.629 & $* * *$ & Soil pH & 0.915 & * \\
\hline Coverage of GR-group, $\%$ & 0.710 & $* * *$ & Proportion of synanthropic species, $\%$ & 0.924 & $*$ \\
\hline Fresh herbage yield, $10^{2} \mathrm{~kg} \mathrm{ha}^{-1}$ & 0.685 & $* * *$ & Number of F-group species, $\%$ & 0.926 & $*$ \\
\hline Simpson index & 0.872 & $* *$ & Bulk density, $\mathrm{g} \mathrm{cm}^{-3}$ & 0.943 & ns \\
\hline Number of LPI-group species & 0.632 & $* * *$ & Number of GRF-group species & 0.976 & ns \\
\hline Species richness & 0.640 & **** & Coverage of GRF-group, $\%$ & 0.992 & ns \\
\hline Coverage of F-group, $\%$ & 0.876 & ** & Coverage of LPI-group, $\%$ & 0.986 & ns \\
\hline Shannon index & 0.840 & $* * *$ & Number of GR-group species & 0.982 & ns \\
\hline Vegetation coverage, $\%$ & 0.832 & $* * *$ & Soil moisture, $\%$ & 0.997 & ns \\
\hline Humus content, $\%$ & 0.870 & $* *$ & Humus stock, $10^{3} \mathrm{~kg} \mathrm{ha}^{-1}$ & 0.991 & ns \\
\hline Dry herbage yield, $10^{2} \mathrm{~kg} \mathrm{ha}^{-1}$ & 0.869 & $* *$ & & & \\
\hline
\end{tabular}

$*, * *, * * *$ Significant at the $0.05,0.01$ and 0.001 probability levels, respectively; ns: nonsignificant at the 0.05 probability level; $\mathrm{n}=126$.

GR-group: Grazing-resistant species group; LPI-group: less palatable and inedible species group; F-group: forage species group; GRF-group: grazing-resistant forage species group.

Figure 3. Significance of differences in vegetation and soil parameters that affected the identification of four grassland degradation stages (DS0-DS3).
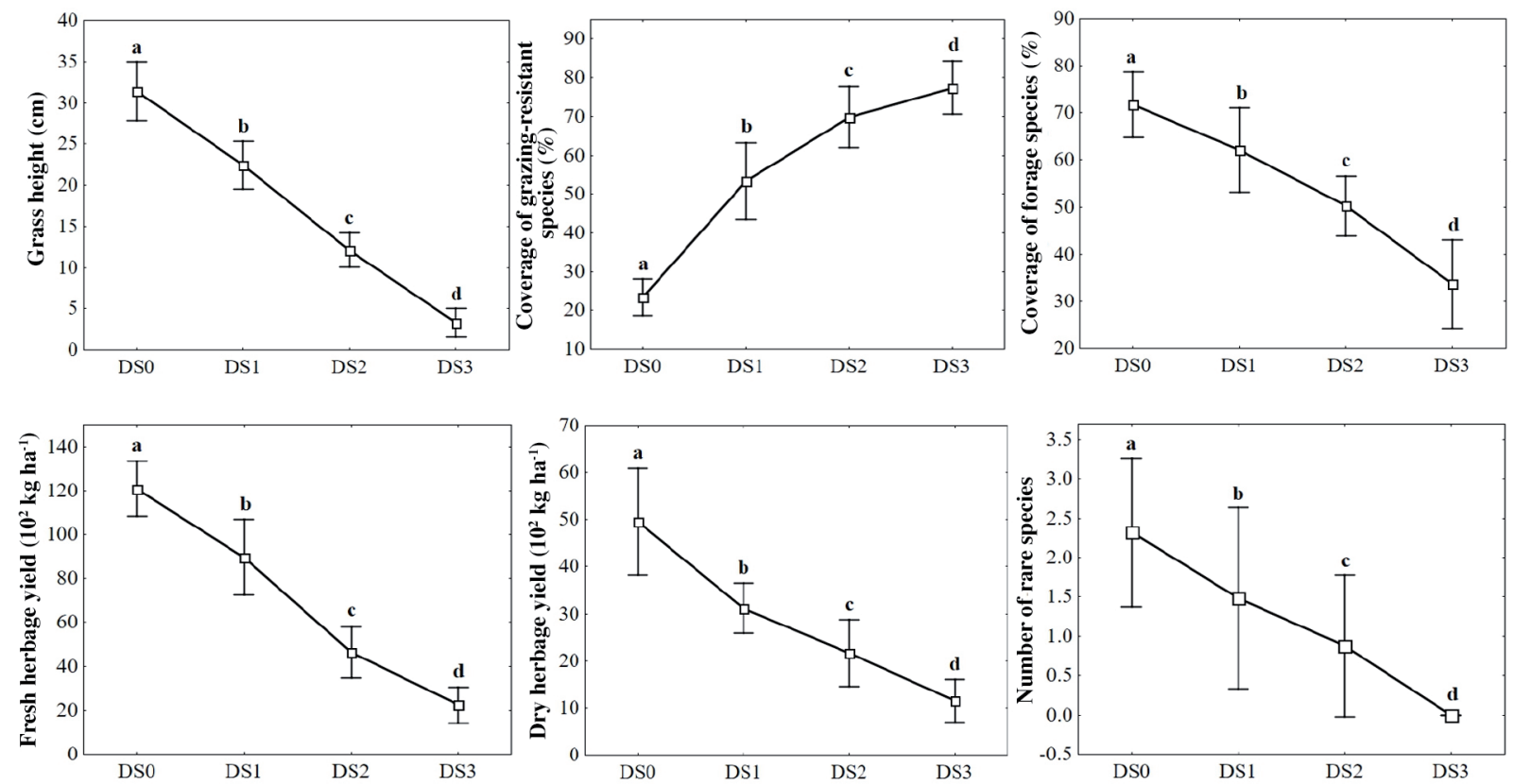

Values are the mean of data averaged across the model plots $(n=126)$; error bars indicate \pm standard deviation of mean. Means with different letters above the bars for each studied parameter are different according to the LSD test at the 0.05 level of probability.

DS0: Untransformed grasslands; DS1: least degraded grasslands; DS2: moderately degraded grasslands; DS3: severely degraded grasslands.

Six vegetation and soil parameters differentiated $(\mathrm{P}<0.05)$ three of four DSs. They were vegetation coverage, humus content, species richness, and Shannon, Berger-Parker and Simpson indices (Figure 4). Vegetation coverage was lower at DS2 than at DS1 and DS0, but the result was not different when compared with DS3. Species richness showed a similar trend from DS0 to DS3. Difference among the means of Shannon index was nonsignificant (P>0.05) at DS0 and DS1. Shannon index increased at DS2 and then decreased at DS3, which showed the greatest species diversity and evenness at DS2. Berger-Parker and Simpson indices confirmed the high degree of dominance at DS0 and DS3. Considering the high positive factor loads of Berger-Parker and Simpson indices on Root 2, this explained the similar location of DS0 and DS3 on the axis of Root 2. The trends of these indices were opposite to the trend of Shannon index. Humus content decreased with degradation intensity due to a decrease in soil organic matter sourced from plant litter. This result was more marked between DS0 and DS3, while DS1 and DS2 did not differ $(\mathrm{P}>0.05)$ in humus content. 
Figure 4. Significance of differences in vegetation and soil parameters that distinguished three of four grassland degradation stages (DS0-DS3).
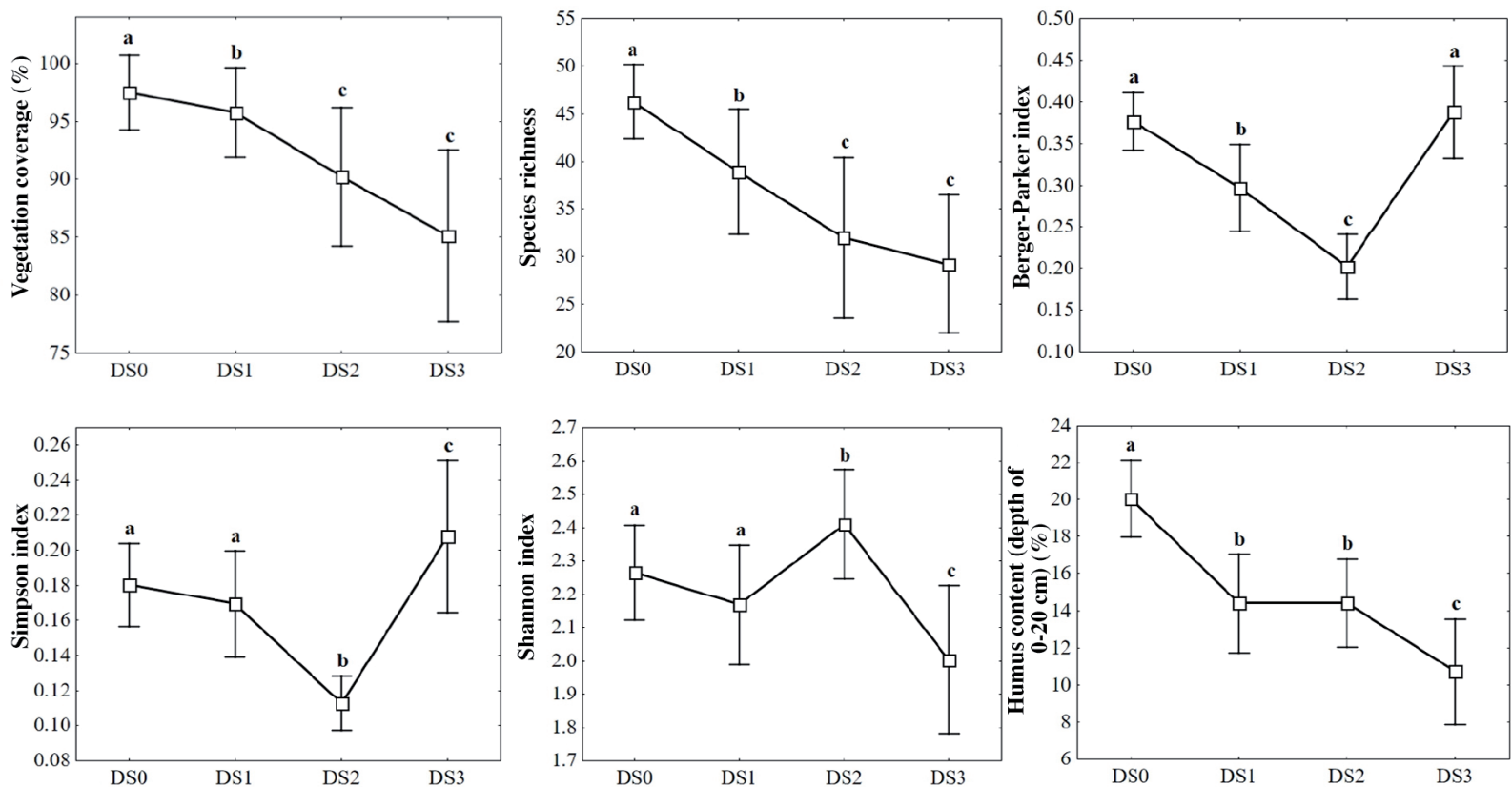

Values are the mean of data averaged across the model plots $(n=126)$; error bars indicate \pm standard deviation of mean. Means with different letters above the bars for each studied parameter are different according to the LSD test at the 0.05 level of probability.

DS0: Untransformed grasslands; DS1: least degraded grasslands; DS2: moderately degraded grasslands; DS3: severely degraded grasslands.

Number of F- and LPI-groups species, soil pH, and proportion of synanthropic species were the least significant in DSs identification. Nevertheless, there were differences $(\mathrm{P}<0.05)$ in number of LPI-group species at DS0 and in proportion of synanthropic species at DS3 (Figure 5). Difference between DS0, DS1 and DS2, DS3 in number of F-groups species was significant, as was the difference between DS0 and DS3 in soil pH. Bulk density continually increased in the row from DS0 to DS3; however, the contribution of this parameter to DSs differentiation was nonsignificant $(\mathrm{P}>0.1)$ in accordance with LDA. Soil moisture did not differ between DS0, DS1 and DS2, and did not matter in DSs identification.

\section{Degradation index (DI) and its scaling}

Thus, the most important indicators that differentiated $(\mathrm{P}<0.05)$ all four stages of grassland degradation were grass height, coverage of GR- and F-groups of species, fresh and dry herbage yield. We used these parameters in multiple regression analysis to calculate DI. The model explained approximately $97 \%$ of variation in independent variables at $\mathrm{P}<0.00001$ significance level; the predicted and adjusted regression coefficients $\left(\mathrm{R}^{2}\right.$ and $\left.\mathrm{Adj} . \mathrm{R}^{2}\right)$ were within 0.001 of each other (Table 3), and the standard error of estimate (SEE) was quite low. These characteristics implied that the model was significant. Grass height was the most important variable according to its regression coefficient (b). It is followed by fresh herbage yield, coverage of F-groups of species, and coverage of GR-groups of species with non-zero regression coefficients. Dry herbage yield was the only nonsignificant parameter $(P>0.05)$ in DSs identification. Decreases in grass height, fresh herbage yield, and coverage of F-groups of species with negative regression coefficients indicated an increase in grassland degradation. Coverage of GR-groups of species displayed a positive relationship with degree of grassland degradation. Obviously, these four variables are relatively easy to measure in the field.

Degradation index values calculated for each stage of grassland degradation according to the regression model (oneway ANOVA) represented a clear and demonstrable row, where DS0 was $0 \pm 0.23$, DS1 was $1 \pm 0.19$, DS2 was $2 \pm 0.16$, and DS3 was to $3 \pm 0.14$ (Figure 6). 
Figure 5. Significance of differences in vegetation and soil parameters that distinguished less than three grassland degradation stages (DS0-DS3) or did not identify the stages according to linear discriminant analysis.
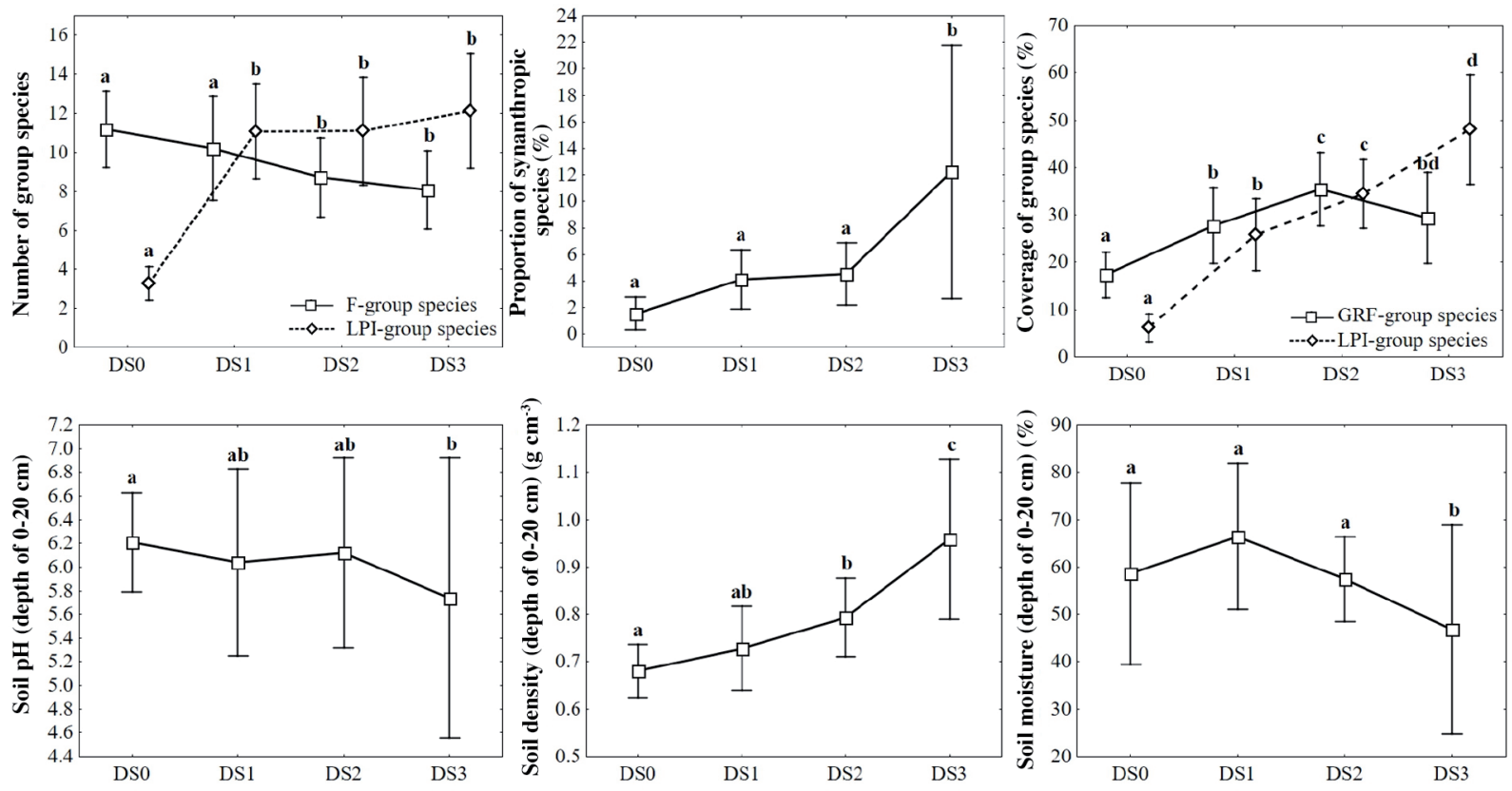

Values are the mean of data averaged across the model plots $(\mathrm{n}=126)$; error bars indicate \pm standard deviation of mean. Means with same letters above the bars for each studied parameter are not different according to the LSD test at the 0.05 level of probability.

DS0: Untransformed grasslands; DS1: least degraded grasslands; DS2: moderately degraded grasslands; DS3: severely degraded grasslands; F-group: forage species; GRF-group: grazing-resistant forage species; LPI-group: less palatable and inedible species.

Coverage of GRF- and LPI-groups species, bulk density and soil moisture did not identify the grassland degradation stages according to the linear discriminant analysis.

Table 3. Multiple regression analysis data showing significance levels of independent variables (vegetation parameters) in identification of the grassland degradation stages.

\begin{tabular}{|c|c|c|c|c|}
\hline Independent variable & $\begin{array}{c}\text { Variable } \\
\text { code }\end{array}$ & $\mathrm{b}$ & $\begin{array}{l}\text { Standard } \\
\text { error of } b\end{array}$ & t-test \\
\hline Intercept & & 2.736 & 0.173 & $*$ \\
\hline Grass height, $\mathrm{cm}$ & A & -0.048 & 0.006 & $*$ \\
\hline Fresh herbage yield, $10^{2} \mathrm{~kg} \mathrm{ha}^{-1}$ & B & -0.009 & 0.002 & $*$ \\
\hline Coverage of F-groups of species, $\%$ & $\mathrm{D}$ & -0.009 & 0.002 & $*$ \\
\hline Coverage of GR-groups of species, $\%$ & E & 0.010 & 0.002 & $*$ \\
\hline Dry herbage yield, $10^{2} \mathrm{~kg} \mathrm{ha}^{-1}$ & $\mathrm{C}$ & 0.005 & 0.003 & ns \\
\hline Mathematical model & $\mathrm{R}^{2}$ & Adj. $R^{2}$ & P-value & SEE \\
\hline $\mathrm{DI}=2.74-0.05 \times \mathrm{A}-0.01 \times \mathrm{B}-0.01 \times \mathrm{C}+0.01 \times \mathrm{D}$ & 0.973 & 0.972 & $<0.00001$ & 0.199 \\
\hline
\end{tabular}

The most valuable grasslands for long-term grazing were at DS1 and DS2 with relatively high forage value and grazing resistance, respectively. To maintain grasslands at the DS1 and DS2 states, it is necessary to regulate the stocking rates. Actual stocking rates for the grasslands at DS1 (21\% of model plots) and DS2 (19\% of model plots) did not exceed the average permissible stocking rates, which were 28 and 14 sheep ha ${ }^{-1} \mathrm{~d}^{-1}$, respectively (Table 4). At the same time, $37 \%$ of model plots were severely degraded grasslands (DS3), where, with the permissible stocking rates of no more than 2-12 sheep $\mathrm{ha}^{-1} \mathrm{~d}^{-1}$, the actual stocking rates were 2-13 times higher. 
Figure 6. Grassland degradation index values for the grassland degradation stages (DS0-DS3).

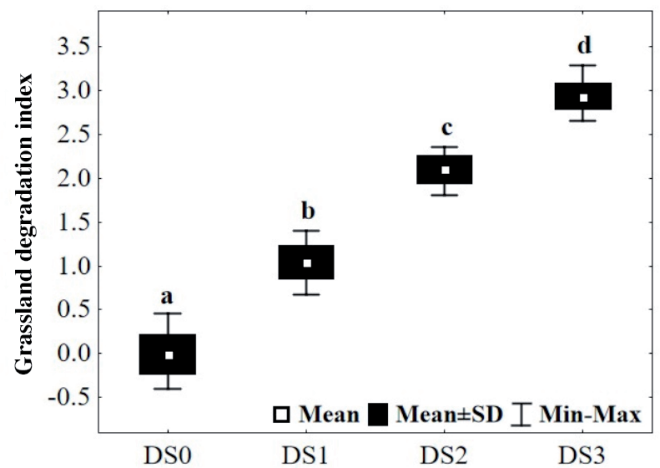

Means with different letters above the bars are different according to the LSD test $(\mathrm{P}<0.05) ; \mathrm{n}=126$.

DS0: Untransformed grasslands; DS1: least degraded grasslands; DS2: moderately degraded grasslands; DS3: severely degraded grasslands.

Table 4. Actual and permissible stocking rates for different degradation stages (DS0-DS3) in grasslands of the Central Caucasus.

\begin{tabular}{|c|c|c|c|c|c|c|c|c|c|c|c|c|}
\hline \multirow[b]{2}{*}{ DS } & \multicolumn{4}{|c|}{$\begin{array}{l}\text { Actual stocking rates } \\
\left(\text { sheep } \mathrm{ha}^{-1} \mathrm{~d}^{-1}\right)\end{array}$} & \multicolumn{4}{|c|}{$\begin{array}{l}\text { Permissible stocking rates } \\
\left(\text { sheep ha-1 } \mathrm{d}^{-1}\right)\end{array}$} & \multicolumn{4}{|c|}{$\begin{array}{l}\text { The ratio of the actual and } \\
\text { permissible stocking rates }\end{array}$} \\
\hline & Mean & $\begin{array}{l}\text { Std. } \\
\text { dev. }\end{array}$ & Min & Max & Mean & $\begin{array}{l}\text { Std. } \\
\text { dev. }\end{array}$ & Min & Max & Mean & $\begin{array}{l}\text { Std. } \\
\text { dev. }\end{array}$ & Min & Max \\
\hline DS0 & 0.0 & 0.0 & 0 & 0 & 37.2 & 3.8 & 28 & 46 & 0.0 & 0.00 & 0.0 & 0.0 \\
\hline DS1 & 6.4 & 3.1 & 3 & 15 & 27.6 & 5.3 & 21 & 46 & 0.2 & 0.12 & 0.1 & 0.6 \\
\hline DS2 & 10.9 & 4.3 & 3 & 20 & 14.2 & 3.6 & 9 & 20 & 0.8 & 0.30 & 0.3 & 1.4 \\
\hline DS3 & 26.9 & 14.9 & 15 & 70 & 6.9 & 2.5 & 2 & 12 & 4.4 & 2.40 & 1.8 & 13.5 \\
\hline
\end{tabular}

DS0: Untransformed grasslands; DS1: least degraded grasslands; DS2: moderately degraded grasslands; DS3: severely degraded grasslands.

\section{DISCUSSION}

The aim of this study was to define the criteria for the stages of grassland degradation for evaluating the grassland status in the field. We developed a four-stage system (DS0-DS3) based on vegetation and soil parameters. Our results showed that grass height, coverage of GR- and F-groups of species, fresh and dry herbage yield, and number of rare species were different $(\mathrm{P}<0.05)$ among all four DSs (Table 2, Figure 3). These results supported previous reports that in grasslands, vegetation parameters such as height and biomass were the main and early indicators for assessing changes imposed by grazing intensity (Mayel et al., 2021). A significant decrease $(\mathrm{P}<0.05)$ in grass height, fresh and dry herbage yield with an increase in degradation intensity is in line with Haider et al. (2011) and Wei et al. (2011), who observed a decrease in these parameters with high stocking rates in grasslands of Pakistan and Tibetan plateau, respectively. Herbivores bite off shoot apices and consume up to $60 \%$ of herbage biomass (Krzic et al., 2013) resulting in a lower growth rate and herbage yield. In this context, it is important to be able to visually recognize the critical value of these parameters, which, for example, for DS2 were $12.13 \pm 2.07 \mathrm{~cm}$ of grass height, and $46.32 \pm 11.62 \times 10^{2} \mathrm{~kg} \mathrm{ha}^{-1}$ of fresh herbage yield. Herders can vary the number of animals to maintain grass height or herbage yield above a critical value. For the optimal stocking rates in the steppe of China, the critical value of average herbage dry mass over summer was about $500 \mathrm{~kg} \mathrm{ha}^{-1}$ (Kemp et al., 2020).

Decrease in coverage of F-group of species in the row DS0-DS3 was accompanied by a significant increase in coverage of GR-group of species (Figure 3). Obviously, an increase in grazing is less favorable for palatable grazingsensitive species (F-group) and more beneficial for palatable grazing-resistant species (GRF-group) and especially for non-preferred species (LPI-group). Therefore, a decrease in coverage of primary dominant Bromus variegatus, one of the most valuable forage species, with moderate and heavy grazing (DS2 and DS3) was accompanied by an increase in coverage of grazing-resistant secondary dominants from GRF- and LPI-groups. The main secondary dominants from GRF-group were Carex humilis, Festuca valesiaca, F. ovina, Agrostis capillaris, Trifolium ambiguum, and the main secondary dominants from LPI-group were Deschampsia cespitosa, Veratrum lobelianum, species of genera Trifolium, Ranunculus, Alchemilla, Plantago, Cirsium. This result is consistent with a previous study of grasslands in Pakistan 
(Haider et al., 2011), which showed that the secondary dominant Bothriochloa pertusa (L.) A. Camus, difficult to graze due to its creeping shoots, replaced the palatable primary dominant Heteropogon contortus (L.) P. Beauv. ex Roem. \& Schult. with continuous grazing. Kemp et al. (2020) also reported that the shift from palatable to less palatable species is a typical pattern in grassland degradation found in many grassland ecosystems. Muller et al. (2021) observed that many palatable and productive species, which are indicators of undisturbed grasslands, were severely reduced with a long legacy of stock grazing; and many grazing-resistant species, which are indicators of disturbance, spread across transformed grasslands. The change in coverage of GR-group species from DS0 to DS2 visually correlated with the change in coverage of GRF-group (Figures 3 and 5). This regularity proves that grazing-resistance forage species were mainly responsible for grazing resistance of grasslands at the stages of moderate degradation. The change in coverage of GR-group species from DS2 to DS3 was consistent with the change in coverage of LPI-group species (Figures 3 and 5), indicating that less palatable and inedible species mainly caused the grazing resistance of grasslands at the stage of severe degradation. A sharp decrease in coverage of GRF-group species at DS3 (Figure 5) confirmed this result. Mayel et al. (2021) also concluded that the percentage of grazing-resistance forage grasses first increases with continuous and high stocking rates, and then unpalatable forbs start to proliferate.

Number of rare species decreased in transformed grasslands down to zero at DS3. Species of families Orchidaceae Juss, Liliaceae Juss, and Iridaceae Juss, such as Traunsteinera sphaerica (M. Bieb.) Schltr., Fritillaria latifolia Willd., Lilium monadelphum M. Bieb., Gladiolus tenuis M. Bieb., were extensively disadvantaged by grassland degradation. This result coincided with Muller et al. (2021), who showed that the most grazing-sensitive were the geophytic families Iridaceae and Hyacinthaceae Batsch ex Borkh. because of their sensitivity to soil disturbance.

Present study revealed that vegetation coverage decreased with increasing grazing intensity. This result supports previous reports that vegetation coverage in grasslands highly depends on grazing intensity (Haider et al., 2011; Kemp et al., 2020; Mayel et al., 2021). However, the stages of moderate and heavy grazing (DS2 and DS3) did not differ in vegetation coverage due to its high variability (Figure 4). Two opposite processes, such as devegetation due to grazing and overgrowing of bare ground with grazing-resistant species (F. valesiaca, C. humilis, T. ambiguum, Rumex confertus, Carduus nutans, etc.), caused the destabilization of vegetation coverage at DS2 and DS3. Grazing intensity affected species richness; however, there was no difference between DS2 and DS3 in this parameter due to its high variability (Figure 4). Opposite processes, such as elimination of forage species (B. variegatus, Phlum phleoides, Koeleria macrantha, etc.) and introduction of grazing-resistant species, destabilized species richness at DS2 and DS3. Previous studies also indicated that grazing may have a negative (Muller et al., 2021) or positive (Mayel et al., 2021) effect on species richness.

DS2 showed the highest species diversity and evenness along with the lowest degree of dominance according to Shannon, Berger-Parker and Simpson indices (Figure 4). This stage of grassland degradation differed from others in the absence of evident dominant species. The coverage of primary dominant B. variegatus decreased to 5\%-10\% at DS2 due to selective grazing behavior of animals, while the coverages of secondary dominants (Trifolium, Ranunculus, Alchemilla, Plantago, etc.) remained relatively low. Therefore, the grasslands at DS0-DS1 and DS3 dominated by primary and secondary dominants, respectively, showed the least species diversity and evenness along with the highest degree of dominance. Thus, diversity and evenness of grasslands increased with moderate grazing and then decreased at the stage of severe degradation. These results partially supported previous studies. Muller et al. (2021) revealed the significantly less diversity and evenness in transformed grasslands since some species became more dominant. Meanwhile, Török et al. (2021) concluded that disturbances promote species diversity by reducing the biomass of dominant grasses.

In this study, grazing intensity affected humus content (Figure 4) through the decrease in plant litter mass, which is consistent with the results of Liu et al. (2011). Bulk density continually increased with degradation intensity (Figure 5). Zhang et al. (2019) associated soil compaction primarily with animal trampling and showed that bulk density increases with increasing trampling intensity by each animal. Soil moisture and $\mathrm{pH}$ were the least significant soil parameters in DSs identification due to high variabilities at each stage of degradation. However, there was a difference $(\mathrm{P}<0.05)$ between DS0 and DS3 in these parameters (Figure 5). Soil moisture was also the lowest due to the highest animal load in the eastern alpine meadows of the Qinghai-Tibet plateau in China (Liu et al., 2016). Intensive grazing negatively affects the soil moisture capacity by changing soil aggregate structure and decreasing organic matter (Guo et al., 2020). Zhang et al. (2019) concluded that soil pH increased with grazing intensity in the grasslands of the Canadian Rocky Mountains due to the approach of carbonates to the soil surface. 
Assessment of grassland status using the four-stage system resulted in $21 \%, 19 \%$, and $37 \%$ of grasslands were at the DS1, DS2, and DS3 stages of degradation, respectively. In the worst cases (DS3), there were clear evidences of poisonous plant expansion, soil erosion, and steppe formation, which indicated that the grasslands needed urgent restoration. However, the actual stocking rates within the highly degraded grasslands were up to 13 times higher than the permissible stocking rates (Table 4). The ability and willingness of herders to vary animal numbers depending on DSs are crucial for maintenance and restoration of grasslands. However, since 2010, animal densities in grasslands have increased dramatically, in places to unacceptable levels. Over the past three decades, Russia had major political changes, which affected the livestock numbers in Caucasian grasslands and became important prerequisites for the modern grazing system and the current state of grasslands. Until the early 1990s, herders in the study area were organized into large collective farms with more than $2.9 \mathrm{~m}$ sheep equivalents (Pshegusov and Chadaeva, 2020). Liquidation of the collective farm system in 1990s and subsequent economic downturn led to a reduction in livestock numbers to $2.2 \mathrm{~m}$ sheep equivalents by 2005 . During this period, mountain grasslands were mostly in acceptable condition. From 2006 to 2010, the livestock numbers stabilized, then after economic growth began in Russia, there was a recovery period in livestock numbers $(3.1 \mathrm{~m}$ sheep equivalents by 2019) in the study area (Pshegusov and Chadaeva, 2020). Traditional herders and collective farmers in the Caucasus followed a transhumant system, moving two or three times a year from subalpine to alpine meadows. Since 2010, animal movements were limited due to the market-oriented grassland rental. Herders rent land from municipalities and use these land plots for grazing in the summer, resulting in overgrazing due to a large number of herders and small size of the rented land plots. Loss of herd mobility and excessively high animal density is the dominant theory to explain grassland degradation in the Central Caucasus. In addition, overgrazing in rented land is due to a lack of market incentives in rational land use for herders seeking to maximize short-term returns to cover rent. There is also weak monitoring of sustainable land use by lessors. Grassland rental should be supported, but there is a clear need to strengthen monitoring and management systems to ensure sustainable land use, prevent degradation and restore disturbed grasslands.

Based on an analysis of historical aspects of pasture exploitation in Kenya, Boles et al. (2019) also showed that the main cause of grassland degradation in the region was the pasture compression and restriction of herd mobility due to inappropriate management policies. Kemp et al. (2020) and Su et al. (2021) observed that under the current 1-yr land lease system in China, there are no incentives for herders to manage appropriately, and rented land within limited areas is often overgrazed. Dong et al. (2021) also demonstrated the importance of re-establishing mobility in rangeland use for grassland restoration and sustainable management in China. Kemp et al. (2020) concluded that for sustainable land use, herders do not need to reduce stocking rates in all grasslands in China, but they can vary their animal numbers to maintain herbage mass above a critical value. This conclusion is consistent with our study; however, we did not use particular vegetation parameters, but the critical values of the integral grassland degradation index (DI). We agree with Dong et al. (2021) that for pasture recovery, new mobile grazing systems must integrate with advanced rangeland management techniques (smart fences, intelligent livestock wearables, drones) and traditional practices (supplementary feeding, soil nutrient replenishment, etc.) Similarity of our findings in the Caucasus to previous studies in China and Kenya may be due to the similarities between the past management legacies in these regions, as well as their current pasture lease systems. However, the impacts of grazing on grasslands depend on local non-management factors such as topography, climate, soil structure, vegetation types, which requires a tailor-made approach to sustainable grassland management (Mayel et al., 2021).

\section{CONCLUSIONS}

Assessment of grassland status using the four-stage system is an effective method for non-professionals including herders, lessors, or municipal managers in evaluating the grassland status in the field. Our study showed that the main indicators of grassland degradation were grass height, fresh herbage yield, coverage of forage species, and coverage of grazing-resistant species. First three parameters decreased significantly with each stage of grassland degradation, while coverage of grazingresistant species increased with degradation intensity. Grazing-resistance forage species were mainly responsible for the grassland grazing resistance at the stages of moderate degradation, while less palatable and inedible species caused the grassland grazing resistance at the stage of severe degradation. Regression model based on these four parameters allowed us to calculate the integral grassland degradation index. Knowledge of critical values of this index for each stage of grassland degradation is useful for a reliable assessment of the grassland status in the field. Soil parameters were less influential on grassland differentiation compared to vegetation parameters. The only significant indicators were humus content and soil $\mathrm{pH}$. 
In total, $37 \%$ of grasslands were at the severe stage of degradation, characterized by the lowest grass height, herbage yield, fodder value, species diversity, humus content, and soil moisture, the highest bulk density, and the dominance of less palatable and inedible species. The actual stocking rates should be reduced by 2-13 times for gradual restoration of these grasslands on rented plots. There is also a clear need to strengthen monitoring and management systems to prevent degradation and restore grasslands.

\section{ACKNOWLEDGEMENTS}

This study was performed as part of the State Assignment, project nr 075-00347-19-00 (Patterns of the spatiotemporal dynamics of meadow and forest ecosystems in mountainous areas (Russian Caucasus)).

\section{REFERENCES}

Amidzic, L., Djordjević-Milošević, S., Vujčić-Trkulja, M., Cvetković, D., Djordjević, S., and Prodanović, D. 2020. Vegetation overview of meadows and pastures of north-west Šar-Planina Mountain (Serbia). Vegetos 33:239-246. doi:10.1007/s42535-020-00101-0.

Boles, O.J.C., Shoemaker, A., Courtney Mustaphi, C.J., Petek, N., Ekblom, A., and Lane, P.J. 2019. Historical ecologies of pastoralist overgrazing in Kenya: Long-term perspectives on cause and effect. Human Ecology 47:419-434. doi:10.1007/s10745-019-0072-9.

Dong, Y.-X., Xue, J.-G., Pan, Q.-M., and Huang, J.-H. 2021. Mobility loss and its restoration in China grasslands. Journal of Applied Ecology 32:406-414. doi:10.13287/j.1001-9332.202102.026.

Guo, X., Dai, L., Li, Q., Qian, D., Cao, G., Zhou, H., et al. 2020. Light grazing significantly reduces soil water storage in alpine grasslands on the Qinghai-Tibet plateau. Sustainability 12(6):2523. doi:10.3390/su12062523.

Haider, M., Maclaurin, A., Chaudhry, A., Mushtaque, M., and Ullah, S. 2011. Effect of grazing systems on range condition in Pabbi Hills Reserve Forest, Kharian, Punjab, Pakistan. Chilean Journal of Agricultural Research 71:560-565.

Hammer, O., Harper, D.A.T., and Ryan, P.D. 2001. PAST: Paleontological statistics software package for education and data analysis. Palaeontologia Electronica 4(1):4.

Kazeev, K.Sh., Kolesnikov, S.I., and Valkov, V.F. 2003. Biological diagnostics and indication of soils: methodology and research methods. Rostov University Press, Rostov-on-Don, Russia.

Kemp, D., Behrendt, K., Badgery, W., Han, G., Li, P., Zhang, Y., et al. 2020. Chinese degraded grasslands - pathways for sustainability. The Rangeland Journal 42:339-346. doi:10.1071/RJ20033.

Krzic, M., Lamagna, S.F., Newman, R.F., Bradfield, G., and Wallace, B.M. 2013. Long-term grazing effects on rough fescue grassland soils in southern British Columbia. Canadian Journal of Soil Science 94:337-345. doi:10.4141/cjss2013-019.

Lazareva, V.G., Bananova, V.A., and Van Zung, N. 2020. Dynamics of modern vegetation for pasture use in the Northwestern Pre-Caspian Region. Arid Ecosystems 10:276-283. doi:10.1134/S2079096120040137.

Lee, B.H., Kim J.Y., Park, H.S., Sung, K.I., and Kim, B.W. 2020. Evaluation of grassland grade by grassland vegetation ratio. Journal of the Korean Society of Grassland and Forage Science 40:29-36. doi:10.5333/KGFS.2020.40.1.29.

Leu, S., Mussery, A.M., and Budovsky, A. 2014. The effects of long time conservation of heavily grazed shrubland: a case study in the Northern Negev, Israel. Environmental Management 54:309-319. doi:10.1007/s00267-014-0286-y.

Liu, M., Ouyang, S., Tian, Y., Shuhai W., Zhao, Y., Li, X., et al. 2021. Effects of rotational and continuous overgrazing on newly assimilated C allocation. Biology and Fertility of Soils 57:193-202. doi:10.1007/s00374-020-01516-2.

Liu, K., Sollenberger, L.E., Silveira, M.L., Newman, Y.C., and Vendramini, J. 2011. Grazing intensity and nitrogen fertilization affect litter responses in 'Tifton 85' bermudagrass pastures: I. Mass, deposition rate, and chemical composition. Agronomy Journal 103:156-162. doi:10.2134/agronj2010.0319.

Liu, H., Wu, J., Tian, X., and Du, W. 2016. Dynamic of aboveground biomass and soil moisture as affected by short-term grazing exclusion on eastern alpine meadow of Qinghai-Tibet plateau, China. Chilean Journal of Agricultural Research 76:321-329. doi:10.4067/S0718-58392016000300009.

Mayel, S., Jarrah, M., and Kuka, K. 2021. How does grassland management affect physical and biochemical properties of temperate grassland soils? A review study. Grass and Forage Science 76:1-30. doi:10.1111/gfs.12512.

Muller, M., Siebert, S., Ntloko, B.R., and Siebert, F. 2021. A floristic assessment of grassland diversity loss in South Africa. Bothalia, African Biodiversity \& Conservation 51:1. doi:10.38201/btha.abc.v51.i1.11.

Navarro L.M., and Pereira H.M. 2012. Rewilding abandoned landscapes in Europe. Ecosystems 15:900-912. doi:10.1007/s10021-012-9558-7.

Pshegusov, R.H., and Chadaeva, V.A. 2020. Historical aspects of exploitation of mountain pasture resources in the Kabardino-Balkarian Republic. Reports of Adyghe (Circassian) International Academy of Sciences 20:16-23. doi:10.47928/1726-9946-2020-20-2-16-23.

Red Data Book of the Republic of Kabardino-Balkaria. 2018. Pechatnyy Dvor, Nalchik, Russia. 
Su, L., Tang, J., and Qiu, H. 2021. Intended and unintended environmental consequences of grassland rental in pastoral China. Journal of Environmental Management 285:112-126. doi:10.1016/j.jenvman.2021.112126.

Török, P., Brudvig, L., Kollmann, J., Price, J., and Tóthmérész, B. 2021. The present and future of grassland restoration. Restoration Ecology 29(S1):e13378. doi:10.1111/rec.13378.

Wei, L., Huang, H.-Z., Zhang, Z.-N., and Wu, G.-L. 2011. Effects of grazing on the soil properties and C and $\mathrm{N}$ storage in relation to biomass allocation in an alpine meadow. Journal of Soil Science and Plant Nutrition 11:27-39. doi:10.4067/S0718-95162 011000400003.

Zhang, B., Beck, R., Pan, Q., Zhao, M., and Hao, X. 2019. Soil physical and chemical properties in response to long-term cattle grazing on sloped rough fescue grassland in the foothills of the Rocky Mountains, Alberta. Geoderma 346:75-83. doi:10.1016/j.geoderma.2019.03.029.

Zhang, J., Zhang, L., Liu, W., and Wo, X. 2014. Livestock-carrying capacity and overgrazing status of alpine grassland in the Three-River Headwaters region, China. Journal of Geographical Sciences 24:303-312. doi:10.1007/s11442-014-1089-z. 